\title{
Effect of 6-BA on the Plant Regeneration via Organogenesis from Cotyledonary Node of Cowpea (Vigna unguiculata L. Walp)
}

\author{
Manman Tie ${ }^{1}$, Qian Luo ${ }^{1}$, Yanxia Zhu ${ }^{1} \&$ Huanxiu $\mathrm{Li}^{1}$ \\ ${ }^{1}$ College of Horticulture, Sichuan Agricultural University, Ya'an, Sichuan, China \\ Correspondence: Huanxiu Li, College of Horticulture, Sichuan Agricultural University, Ya'an, Sichuan, China. \\ E-mail: hxli62@163.com
}

Received: January 27, 2013 Accepted: March 1, 2013 Online Published: April 15, 2013

doi:10.5539/jas.v5n5p1 URL: http://dx.doi.org/10.5539/jas.v5n5p1

\begin{abstract}
The present study compares effects of different concentrations of 6-BA on regeneration from cotyledonary node explants of cowpea (Vigna unguiculata L. Walp). The seeds were inoculated on $\mathrm{MSB}_{5}$ medium [Murashige and Skoog (1962) salts and Gamborg $B_{5}$ vitamins (1968)] containing different concentrations $(0,1,2,3,4,5 \mathrm{mg} / \mathrm{L})$ of 6-BA for 4 days. The cotyledonary node explants with one cotyledon excised from 4-day-old seedlings, placed in vitro on $\mathrm{MSB}_{5}$ medium containing 6-BA at different dose $(0,0.5,1.0,1.5 \mathrm{mg} / \mathrm{L})$ for shoot induction and elongation. Best response in terms of shoot number and shoot length were obtained with explants derived from seedling preconditioning with $3 \mathrm{mg} / \mathrm{L}$ 6-BA followed by the induction and elongation stage pretreated with $0.5 \mathrm{mg} / \mathrm{L} 6-\mathrm{BA}$. The elongated shoots were rooted on $\mathrm{MSB}_{5}$ medium without hormone.
\end{abstract}

Keywords: cowpea, plant regeneration, cotyledonary node, organogenesis, 6-BA

Abbreviations: 6-BA: 6-Benzylaminopurine

\section{Introduction}

Cowpea (Vigna unguiculata L.) is widely grown in Africa, Latin America, Southeast Asia and southwestern regions of North America, and is a major source of high-quality dietary protein and energy for local people. It plays an important role in the lives of millions of people in developing countries of Africa and Asia. In spite of the great importance of this crop, its productivity is low, which is mainly limited by the damage caused by biotic and abiotic stresses (Singh et al., 1997). In addition, limited genetic diversity in cowpea breeding programs is of special concern because cowpea appears to have lower inherent genetic diversity than other cultivated crops as a result of a hypothesized single domestication event (Fang et al., 2007). Although some resistance genes to insect pests and fungi have been identified in some IITA cowpea varieties and other closely related Vigna species (Latunde-Dada et al., 1990), the attempts using conventional breeding methods to introduce the resistance genes into the cultivated cowpea have made little progress for the strong hybrid incompatibility. Hence, genetic engineering approaches stand out as the most effective alternative strategy to overcome the production constraints (Zaidi et al., 2005). An effective and rapid regeneration protocol is essential for genetic transformation. Plant regeneration of cowpea via organogenesis has been achieved from epicotyls, hypocotyls, primary leaves, cotyledons, cotyledonary nodes, shoot tips, plumular apices and shoot meristem. Of these, cotyledonary node explants seemed the most responsive for the induction of multiple shoots, which was appropriate to agrobacterium-mediated transformation (Chaudhury et al., 2007; Raji et al., 2008; Solleti et al., 2008a, 2008b; Adesoye et al., 2010).

Previous work has studied the effect of varied hormones used together on the regeneration of cowpea. But the regeneration of cowpea via cotyledonary node uses 6-BA alone has not been explored. The aim of this paper is to explore the effect of 6-BA on different stages of regeneration of cowpea, to provide a theoretical and technical basis for rapid propagation.

\section{Materials and Methods}

\subsection{Plant Materials and Seeds Preconditioning}

Mature seeds of cv. Cheng-jiang VII of cowpea was obtained from the Research Institute of Horticulture, Academy of Chengdu Agriculture and Forestry Science, Chengdu, China. The seeds were soaked with 70\% ethanol for $1 \mathrm{~min}$, surface-sterilized with $0.2 \%(\mathrm{w} / \mathrm{v}) \mathrm{HgCl}_{2}$ for $5 \mathrm{~min}$, followed by rinsed five times with sterile 
distilled water and blotted with sterilized filter papers. Then the seeds were cultured on $\mathrm{MSB}_{5}$ medium supplemented with 6-BA at different concentrations $(0,1,2,3,4,5 \mathrm{mg} / \mathrm{L})$ for 4 days.
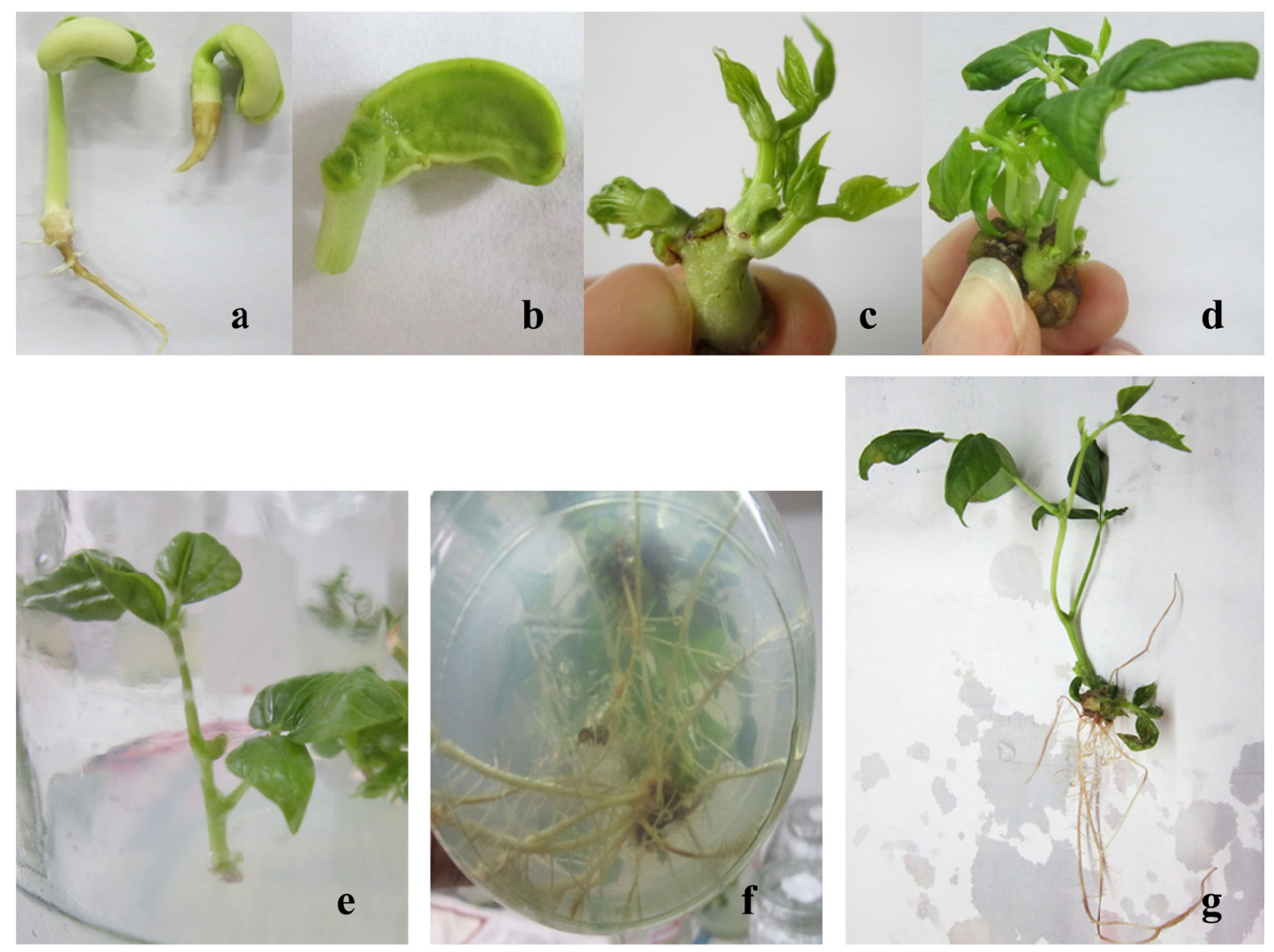

Figure 1. Regeneration system from cotyledonary node explants of cowpea. (a) Seedling preconditioning with 6-BA (right) and seedling without preconditioning (left). (b) Cotyledonary node explants removing one cotyledon and cutting both the epicotyls and hypocotyls. (c) and (d) Explants excised from seedling preconditioning with $3 \mathrm{mg} / \mathrm{L}$ 6-BA, followed by shoot induction and elongation on $\mathrm{MSB}_{5}+0.5 \mathrm{mg} / \mathrm{L}$ 6-BA for two weeks (c) and four weeks (d). (e) Elongated shoots were separated and transferred to hormone-free $\mathrm{MSB}_{5}$ medium for rooting. (f) Elongated shoots forming roots on hormone-free $\mathrm{MSB}_{5}$ medium. (g) Rooted plantlet

\subsection{Shoot Induction and Elongation}

The cotyledonary node explants excised from 4-day-old seedlings were cultured in a vertical upright position with the hypocotyls end slightly embedded in $\mathrm{MSB}_{5}$ medium supplemented with various concentrations of 6 -BA $(0,0.5,1.0,1.5 \mathrm{mg} / \mathrm{l})$. The explants were excised by removing one cotyledon and cutting both the epicotyls and hypocotyls approximately $2 \mathrm{~mm}$ above and 3-5 $\mathrm{mm}$ below the nodal point (Figure 1b). And the initial axillary buds were also removed. After 2 weeks of culture (Figure 1c), the multiple shoots were removed from the explants and transferred to fresh medium with the same concentrations of 6-BA for subculture for another 2 weeks (Figure 1d).

\subsection{Rooting and Acclimatization}

Regenerated shoots were separated and transferred to hormone-free $\mathrm{MSB}_{5}$ medium for rooting (Figure 1e). After 2 weeks of culture, the rooted plantlets (Figure 1g) were washed in running rap water and transferred to pods containing sterilized soil, green manure and vermiculite at 1:1:1 ratio. Each pot was covered with transparent polyethylene bags to maintain adequate humidity during the first few days. Subsequently, the bags were removed and the plants were allowed to grow at room temperature with $50 \%$ relative humidity.

\subsection{Culture Medium and Conditions}

$\mathrm{MSB}_{5}$ medium [Murashige and Skoog (1962) salts and Gamborg $\mathrm{B}_{5}$ vitamins (1968)] supplemented with 3\% $(\mathrm{w} / \mathrm{v})$ sucrose and $0.6 \%(\mathrm{w} / \mathrm{v})$ agar was used throughout this study. The $\mathrm{pH}$ of the medium was adjusted to 5.8 
with $0.1 \mathrm{~N} \mathrm{NaOH}$ or $\mathrm{HCl}$ before autoclaving at $121^{\circ} \mathrm{C}$ for $15 \mathrm{~min}$. All the cultures were maintained at $26 \pm 2^{\circ} \mathrm{C}$ temperature with $16 \mathrm{~h}$ light photoperiod. The experiment started from mid-August and finished in mid to end of October in 2012.

\subsection{Data Collection and Statistical Analysis}

The length and the number of adventitious buds were recorded after 2 weeks of culture on the shoot induction and elongation medium. The date of the shoots began to take roots were also recorded. The experiments were arranged to repeat thrice with 20 replicates per treatment. The data were determined by analysis of variance and the significant difference between the means were compared using Duncan's new multiple range method with the help of statistical software DPS.

\section{Result and Discussion}

\subsection{Effect of 6-BA Preconditioning on Seed Germinating}

Cowpea is recalcitrant to regeneration from shoot proliferation and genetic manipulation (Dita et al., 2006). The regenerative competence could be increased via seedling preconditioning using high dose of cytokinin because of its promoting in cell division.

In this study, the seeds cultured on the medium containing 6-BA grew obviously stronger than those cultured on hormone-free medium. The differences are expressed in following aspects made up of dramatic enlarged primary leaves, stubby hypocotyls, hyperplastic region of the cotyledonary node, and thick and short roots (Figure 1a). This conclusion was similar to some other scholars (Bakshi et al., 2012; Tang et al., 2012). The effect was significantly more pronounced when the concentration of 6-BA was up to $3 \mathrm{mg} / \mathrm{L}$. Looking just from morphological terms, the seedlings showed no obvious differences at high dose $(3,4,5 \mathrm{mg} / \mathrm{L})$ of 6 -BA.

\subsection{Effect of 6-BA on Shoot Induction, Elongation and Rooting}

Table1. Effect of different concentration of 6-BA on shoot regeneration from cotyledonary node explants of cowpea following culture on $\mathrm{MSB}_{5}$ medium for two weeks

\begin{tabular}{|c|c|c|c|}
\hline \multicolumn{2}{|c|}{ Concentration of 6-BA $(\mathrm{mg} / \mathrm{L})$} & \multirow{2}{*}{$\begin{array}{l}\text { Mean number of shoots } \\
\text { per explant }\end{array}$} & \multirow{2}{*}{$\begin{array}{l}\text { Mean shoot } \\
\text { length }(\mathrm{cm})\end{array}$} \\
\hline $\begin{array}{l}\text { Seedling } \\
\text { preconditioning }\end{array}$ & $\begin{array}{l}\text { Shoot induction and } \\
\text { elongation }\end{array}$ & & \\
\hline \multirow{4}{*}{0} & 0 & $1.82 \mathrm{~d}$ & $2.83 \mathrm{ab}$ \\
\hline & 0.5 & $3.68 \mathrm{c}$ & 2.17abcd \\
\hline & 1 & $4.59 \mathrm{ab}$ & $1.50 \mathrm{cde}$ \\
\hline & 1.5 & $4.44 \mathrm{bc}$ & $0.93 \mathrm{e}$ \\
\hline \multirow{4}{*}{1} & 0 & $1.90 \mathrm{~d}$ & $2.93 \mathrm{ab}$ \\
\hline & 0.5 & $4.93 \mathrm{ab}$ & $2.50 \mathrm{abc}$ \\
\hline & 1 & $5.30 \mathrm{ab}$ & $2.33 \mathrm{abcd}$ \\
\hline & 1.5 & $4.97 \mathrm{ab}$ & $1.86 \mathrm{bcde}$ \\
\hline \multirow{4}{*}{2} & 0 & $2.27 \mathrm{~d}$ & $2.53 \mathrm{abc}$ \\
\hline & 0.5 & $5.17 \mathrm{ab}$ & $1.97 \mathrm{bcde}$ \\
\hline & 1 & $4.89 \mathrm{ab}$ & 2.17abcd \\
\hline & 1.5 & $5.32 \mathrm{ab}$ & $1.47 \mathrm{cde}$ \\
\hline \multirow{4}{*}{3} & 0 & $2.23 \mathrm{~d}$ & $3.20 \mathrm{a}$ \\
\hline & 0.5 & $5.20 \mathrm{ab}$ & $2.80 \mathrm{ab}$ \\
\hline & 1 & $5.10 \mathrm{ab}$ & $2.40 \mathrm{abcd}$ \\
\hline & 1.5 & $5.13 \mathrm{ab}$ & $1.53 \mathrm{cde}$ \\
\hline \multirow{4}{*}{4} & 0 & $2.00 \mathrm{~d}$ & $3.10 \mathrm{a}$ \\
\hline & 0.5 & $5.30 \mathrm{ab}$ & $2.22 \mathrm{abcd}$ \\
\hline & 1 & $5.41 \mathrm{ab}$ & 1.93 bcde \\
\hline & 1.5 & $5.15 \mathrm{ab}$ & $1.37 \mathrm{de}$ \\
\hline \multirow{4}{*}{5} & 0 & $2.13 \mathrm{~d}$ & $3.10 \mathrm{a}$ \\
\hline & 0.5 & $5.53 \mathrm{a}$ & $2.49 \mathrm{abc}$ \\
\hline & 1 & $5.42 \mathrm{ab}$ & $1.88 \mathrm{bcde}$ \\
\hline & 1.5 & $5.33 \mathrm{ab}$ & $1.60 \mathrm{cde}$ \\
\hline
\end{tabular}

Values represent means. Means having the same letters are not significantly different according to Duncan's multiple range test at $P=0.05$. 
At the stage of shoot induction and elongation, more adventitious buds were observed on the media supplement with 6-BA compared with that of control. When the concentration of 6-BA was $0.5 \mathrm{mg} / \mathrm{L}, 1.0$ $\mathrm{mg} / \mathrm{L}$ and $1.5 \mathrm{mg} / \mathrm{L}$, the number of shoots per explant displayed increasing but the distinction was not very significant (Table 1). This might be because higher concentration of 6-BA precondition at the stage of seedlings made a large impact on the following stage (Brar et al., 1999; Le et al., 2002; Raveendar et al., 2009). The shoot length was decreased with the concentration of 6-BA increasing, which was in agreement with the research of pioneers (Diallo et al., 2008; Aasim et al., 2009; Tang et al., 2012). Besides, it is important to note that when the concentration of 6-BA was $1.5 \mathrm{mg} / \mathrm{L}$, abnormal morphology of shoots would be observed. The stems grew and bend downwards, the leaves were shrunken. And the abnormal shoots were difficult to elongate.

After induction and elongation, the regenerated shoots were removed on $\mathrm{MSB}_{5}$ medium without hormone for rooting. More than $95 \%$ of the regenerative shoots could produce roots. But the time at the beginning of forming roots were different. If the concentration of 6-BA was higher at the stages of induction and elongation, it was difficult to produce roots, which manifested as it would take a longer time to start rooting. The experiment showed that the optimal concentration of 6-BA promoted the propagation of adventitious buds, but inhibit both the shoot elongation and rhizogenesis.

In the present investigation, $3 \mathrm{mg} / \mathrm{L}$ 6-BA preconditioning during the seedlings and $0.5 \mathrm{mg} / \mathrm{L} 6-\mathrm{BA}$ at the induction and elongation stages was the best concentration to induce adventitious buds and to elongate comprehensively considered efficacy and cost.

\section{References}

Aasim, M., Khawar, K. M., \& Ozcan, S. (2009). In vitro micropropagation from plumular apices of Turkish cowpea (Vigna unguiculata L.) cultivar Akkiz. Scientia Horticulturae, 122, 468-471. http://dx.doi.org/10.1016/j.scienta.2009.05.023

Adesoye, A. I., Togun, A. O., \& Machuka, J. (2010). Transformation of cowpea (Vigna unguiculata L.Walp.) by Agrobacterium infiltration. Journal of Applied Biosciences, 30, 1845-1860.

Bakshi, S., Roy, N. K., \& Sahoo, L. (2012). Seedling preconditionng in thidiazuron enhances axillary shoot proliferation and recovery of transgenic cowpea plants. Plant Cell, Tissue and Organ Culture, 110, 77-91. http://dx.doi.org/10.1007/s11240-012-0132-y

Brar, M. S., Al-Khayri, J. M., Morelock, T. E., \& Anderson, E. J. (1999). Genotypic response of cowpea Vigna unguiculata (L.) to in vitro regeneration from cotyledon explants. In Vitro Cellular \& Developmental Biology-Plant, 35, 8-12. http://dx.doi.org/10.1007/s11627-999-0002-4

Chaudhury, D., Madanpotra, S., Jaiwal, R., Saini, R., Kumar, A. P., \& Jaiwal, P. K. (2007). Agrobacterium tumefaciens-mediated high frequency genetic transformation of an Indian cowpea (Vigna unguiculata L. Walp.) cultivar and transmission of transgenes into progeny. Plant Science, 172, 692-700. http://dx.doi.org/10.1016/j.plantsci.2006.11.009

Diallo, M. S., Ndiaye, A., Sagna, M., \& Gassama-Dia, Y. K. (2008). Plants regeneration from African cowpea variety (Vigna unguiculata L. Walp.). African Journal of Biotechnology, 7, 2828-2833.

Dita, M. A., Rispail, N., Prats, E., Rubiales, D., \& Singh, K. B. (2006). Biotechnology approaches to overcome biotic and abiotic stress constraints in legumes. Euphytica, 147, 1-24. http://dx.doi.org/10.1007/s10681-006-6156-9

Fang, J., Chao, C. T., Roberts, P. A., \& Ehlers, J. D. (2007). Genetic diversity of cowpea [Vigna unguiculata (L.) Walp.] in four West African and USA breeding programs as determined by AFLP analysis. Genetic Resources and Crop Evolution, 54(6), 1197-1209. http://dx.doi.org/10.1007/s10722-006-9101-9

Gamborg, O. L., Miller, R. A., \& Ojima, K. (1968). Nutrient requirements of suspension cultures of soybean root cells. Expermental Cell Research, 50, 151-158. http://dx.doi.org/10.1016/0014-4827(68)90403-5

Latunde-Dada, A. O. (1990). Genetic manipulation of the cowpea (Vigna unguiculata [L.] Walp.) for enhanced resistance to fungal pathogens and insect pests. Advances in Agronomy, 44, 133-154.

Le, B. V., Carvalho, M. H., Zuily-Fodil, Y., Thi, A. T., \& Van, K. T. H. (2002). Direct whole plant regeneration of cowpea [Vigna unguiculata (L.) Walp] from cotyledonary node thin cell layer explants. Journal of Plant Physiology, 159, 1255-1258. http://dx.doi.org/10.1078/0176-1617-00789

Murashige, T., \& Skoog, F. (1962). A revised medium for rapid growth and bioassays with tobacco tissue 
cultures. Physiologia Plantarum, 15, 473-497. http://dx.doi.org/10.1111/j.1399-3054.1962.tb08052.x

Raji, A. A. J., Oriero, E., Odeseye, B., Odunlami, T., \& Ingelbrecht, I. L. (2008). Plant regeneration and Agrobacterium-mediated transformation of African cowpea [Vigna unguiculata (L.) Walp] genotypes using embryonic axis explants. Journal of Food, Agriculture \& Environment, 6, 350-356.

Raveendar, S., Premkumar, A., Sasikumar, S., Ignacimuthu, S., \& Agastian, P. (2009). Development of a rapid, highly efficient system of organogenesis in cowpea Vigna unguiculata (L.) Walp. South African Journal of Botany, 75, 17-21. http://dx.doi.org/10.1016/j.sajb.2008.05.009

Singh, B. B., Chambliss, O. L., \& Sharma, B. (1997). Recent advances in cowpea breeding. Advances in Cowpea Research (pp. 30-50).

Solleti, S. K., Bakshi, S., \& Sahoo, L. (2008a). Additional virulence genes in conjunction with efficient selection scheme and compatible culture regime enhance recovery of stable transgenic plants in cowpea via Agrobacterium tumefaciens-mediated transformation. Journal of Biotechnology, 135, 97-104. http://dx.doi.org/10.1016/j.jbiotec.2008.02.008

Solleti, S. K., Bakshi, S., Purkayastha, J., Panda, S. K., \& Sahoo, L. (2008b). Transgenic cowpea (Vigna unguiculata) seeds expressing a bean $\alpha$-amylase inhibitor 1 confer resistance to storage pests, bruchid beetles. Plant Cell Reports, 27, 1841-1850. http://dx.doi.org/10.1007/s00299-008-0606-x

Tang, Y., Chen, L., Li, X. M., Li, J., Luo, Q., Lai, J., \& Li, H. X. (2012). Effect of culture conditions on the plant regeneration via organogenesis from cotyledonary node of cowpea (Vigna unguiculata L. Walp). African Journal of Biotechnology, 11(14), 3270-3275. http://dx.doi.org/10.5897/AJB11.3214

Zaidi, M. A., Mohammadi, M., Postel, S., Masson, L., \& Altosaar, I. (2005). The Bt gene cry2Aa2 driven by a tissue specific ST-LS1 promoter from potato effectively controls Heliothis virescens. Transgenic Research, 14, 289-298. http://dx.doi.org/10.1007/s11248-004-7714-3 